Brit. J. vener. Dis. (1963), 39, 238.

\title{
PROBENECID AS AN ADJUVANT IN THE TREATMENT OF GONORRHOEA WITH PENICILLIN*
}

\author{
BY \\ P. E. JENSEN, S. A. KVORNING, AND K. NØRREDAM \\ Department of Dermatology, Rigshospitalet, and University of Copenhagen, Denmark
}

Even with the decreased sensitivity of Neisseria gonorrhoeae to penicillin, this drug will still be preferable for the treatment of gonorrhoea because of its low toxicity, few side-effects, and moderate price (Willcox, 1962b). We have therefore carried out a series of controlled experiments in the treatment of twenty patients with gonococcal urethritis and cervicitis clinically resistant to our routine treatment with 300,000 international units of procaine penicillin intramuscularly, and with reduced sensitivity of the bacteria to penicillin in vitro. The main therapeutic problem in such patients is to maintain a high concentration of penicillin in the serum. This can be obtained in several ways (Willcox, 1962a). A very rapid increase and high initial concentration may be reached by intramuscular injection of sodium penicillin, but these intramuscular depots will soon be drained and the antibiotic eliminated by chemical inactivation (Rammelkamp and Bradley, 1943; Jensen, Møller, and Overgaard, 1945), which accounts for 70 per cent. of the elimination.

The renal transport mechanism which is responsible for the secretion of penicillin into the urine can be blocked by various means (Boger and Flippin, 1949; Weiner, Washington, and Mudge, 1960) which have served to increase the effect of penicillin in treating gonorrhoea (Jacoby, Pollock, and Boghosian, 1954; Marmell and Prigot, 1957; Schultz and Shaffer, 1958; Hilton, 1959). We have preferred to use probenecid for this purpose because of its low toxicity (Beckmann, 1963) and easy administration (Beyer, Wiebelhaus, Russo, Peck, and McKinney, 1950; Crone and Lassen, 1955).

To demonstrate the effect of probenecid intake on penicillin concentration in the serum, each patient

\footnotetext{
* Paper read at the M.S.S.V.D. meeting in Copenhagen, June 6, 1963.
}

received two injections each of $1,000,000$ international units sodium penicillin.

For 24 hours before and 24 hours after the second injection probenecid was administered in doses of 0.5 or $1 \mathrm{~g}$. every 6 hours. The penicillin concentration in the serum was studied by frequent determinations made in the Antibiotics Division of Leo Pharmaceutical Products, Ltd.

In order to make the patients' stay in hospital as brief as possible, only one bacteriological examination was performed after the first penicillin injection, and this was done immediately before the second injection. After the second injection the patients were followed with weekly examinations for 3 weeks, after which they were regarded as non-contagious.

As could be expected from previous research (Beyer, 1950; Walker and Hunter, 1951; Jacoby and others, 1954; Schultz and Shaffer, 1958), the probenecid administration was followed by a considerable prolongation of a high penicillin concentration in the serum. This was constantly demonstrated in all twenty patients. The duration of the serum concentration above $2 \mu \mathrm{g} . / \mathrm{ml}$. ranged from 1.6 to 4 hours without probenecid and from $3 \cdot 8$ to 10 hours when probenecid had been given. The prolongation for each individual patient varied from 60 to 380 per cent.

Of the twenty patients, thirteen were cured (only one post-treatment examination) with sodium penicillin alone, and a further six were cured by the combined treatment. One patient was not cured in this way and will be discussed later.

We have compared the clinical results for the duration of a serum penicillin concentration which was one, two, three, four, and five times the 50 per cent. growth inhibitory $\left(\mathrm{IC}_{50}\right)$ concentration determined in vitro, this ranging from 0.21 to $1 \cdot 20 \mu \mathrm{g} . / \mathrm{ml}$. or more (tested by the plate dilution method in the 
State Serum Institute under supervision of Dr. Alice Reyn). The results are shown in the Figure, in which the patients are grouped according to the time they maintained one, two, three, four, and five times the $\mathrm{IC}_{50}$ concentration, for periods ranging from less than 2 to 6 or more hours. The diagram clearly indicates that no simple rule can be given for a curative concentration-time relation. However, a high concentration is important and the bacterial cultures became negative even when the penicillin concentration had been raised to a level that could be considered curative for only a few hours.
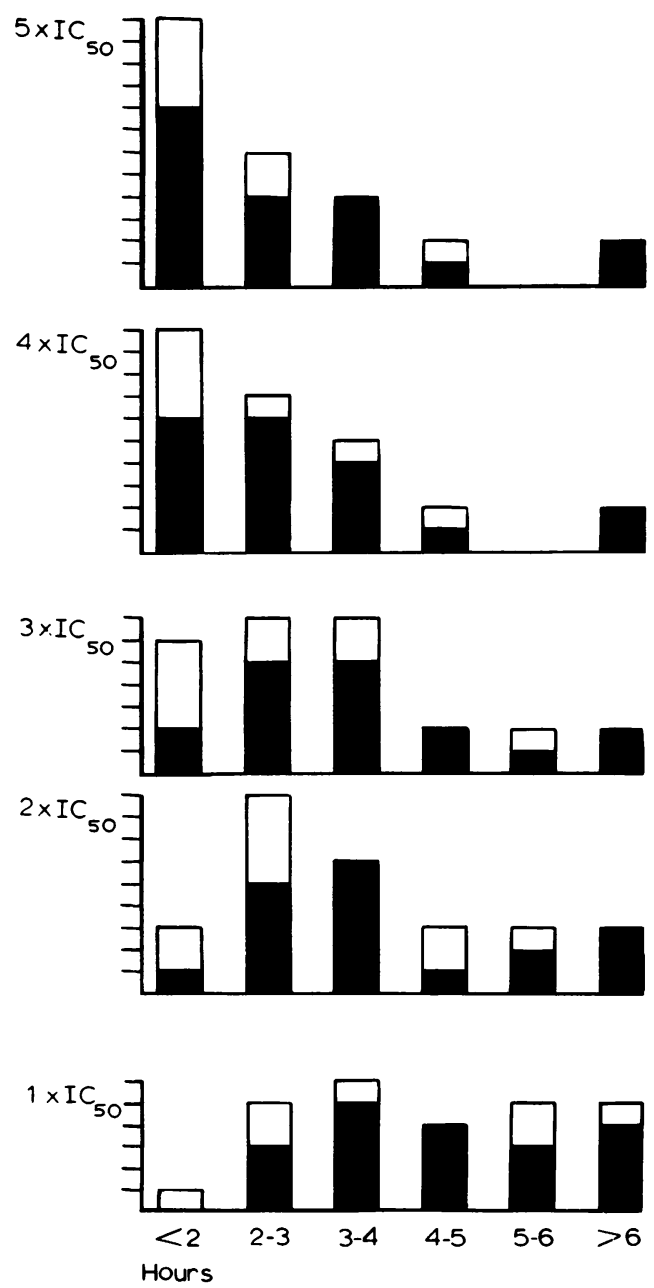

FIGURE.-Each row of columns indicates how many of the patients were cured by maintaining the serum penicillin concentration above a certain level for from less than 2 to more than 6 hours. The lowest row shows the results for the 50 per cent. inhibitory concentrations, the second row for twice this concentration, and so on.
As mentioned above, one patient was still contagious after the combined treatment, although the high concentration was maintained considerably longer in this case than in some in which the infection was cured.

This patient then received two injections of $5,000,000$ i.u. sodium penicillin with an 8 hours' interval, while he was taking probenecid $1 \mathrm{~g}$. four times daily. By this means a serum concentration of $6 \mu \mathrm{g} . / \mathrm{ml}$. (over five times the $\mathrm{IC}_{50}$ ) was maintained for 20 hours and after this he was found to be non-contagious.

\section{Summary}

Twenty patients with uncomplicated gonorrhoea caused by strains of Neisseria gonorrhoeae with reduced sensitivity to penicillin were treated with one dose of $1,000,000$ international units sodium penicillin alone and 2 days later with the same dose plus probenecid 0.5 to $1 \mathrm{~g}$. four times daily.

The serum concentration of penicillin remained elevated much longer when probenecid was added. Only thirteen of the twenty patients gave negative cultures after sodium penicillin alone, but a further six were cured after the combined treatment. One patient required two doses of 5,000,000 i.u. sodium penicillin plus probenecid.

\section{REFERENCES}

Beckmann, H. (ed.) (1963). "The Year Book of Drug Therapy, 1962-63", p. 500.

Beyer, K. H. (1950). Pharmacol. Rev., 2, 227.

-, Wiebelhaus, V. D., Russo, H. F., Peck, H. M., and McKinney, S. E. (1950). Fed. Proc., 9, 258.

Boger, W. P., and Flippin, H. F. (1949). J. Amer. med. Ass., 139, 1131.

Crone, C., and Lassen, U. V. (1955). Acta pharmacol. toxicol., 11, 295.

Hilton, A. L. (1959). Brit. J. vener. Dis., 35, 249.

Jacoby, A., Pollock, J., and Boghosian, V. (1954). Amer. J. Syph., 38, 478.

Jensen, K. A., Møller, K. O., and Overgaard, K. (1945). Acta pharmacol. toxicol., 1, 184.

Marmell, M., and Prigot, A. (1957). Amer. J. med. Sci., 233, 256.

Rammelkamp, C. H., and Bradley, S. E. (1943). Proc. Soc. exp. Biol. $(N . Y$.), 53, 30.

Schultz, J. H., and Shaffer, L. W. (1958). Amer. Practit., 9,922 .

Walker, W. F., and Hunter, R. B. (1951). Lancet, 2, 104.

Weiner, I. M., Washington, J. A., and Mudge, G. H. (1960). Bull. Johns Hopk. Hosp., 106, 333.

Willcox, R. R. (1962a), Brit. J. clin. Pract., 16, 527. (1962b). Ibid., 16, 587. 
Traitement de la blennorragie par la probénécide ajoutée à la pénicilline

RÉSUMÉ

A 20 malades atteints de blennorragie simple due aux souches de Neisseria gonorrhoeae peu sensibles à la pénicilline, on donna une seule dose de 1.000 .000 unités de pénicilline, suivie 2 jours plus tard par la même dose de pénicilline plus de 0,5 à lg. de probénécide quatre fois par jour.

L'élévation du niveau de pénicilline dans le sérum fut prolongée quand on donna également la probénécide; 13 malades sur 20 furent guéris par la pénicilline seule et 6 autres furent guéris par le traitement combiné.

Un malade eut besoin de deux doses de 5.000 .000 unités de pénicilline aussi bien que de la probénécide. 